\title{
Knowledge Management and Improvement in Library Services at Fourah Bay College Library: a Statistical Approach
}

Prince Sao Lahai, Jr. ( $\nabla$ princesaolahai@gmail.com )

Fourah Bay College

\section{Research Article}

Keywords: Analysis of variance, Chi-square distribution, Knowledge management, Fourah Bay College library services, Survey and questionnaires

Posted Date: December 9th, 2021

DOI: https://doi.org/10.21203/rs.3.rs-1155899/v1

License: (9) This work is licensed under a Creative Commons Attribution 4.0 International License.

Read Full License 


\section{Abstract}

The purpose of the paper is to statistically examine the way knowledge management is done at Fourah Bay College in the improvement of library services with the aims of identifying the types of knowledge managed, facilities, equipment, and supplies; policies used to manage the knowledge; knowledge management acquisition skills; relevancy and challenges to managing knowledge at FBC library. The study was informed by the triangulation of the Staff and knowledge Continuum Theories which tend to fill the gap of Robertson and Brun(2021) who considered computer as explicit knowledge. But that gap was filled to indicate knowledge resided in computer as an implicit knowledge in this research. Data used for analysis were drawn from thirty-three(33) participants from six section with the use of questionnaires, personal interview and personal observations. A total of 33 questionnaires were returned in their complete forms and used for the analysis. Both descriptive and inferential statistics were performed by using SPSS version(16.0) to ascertain the relevance of managing knowledge at FBC library in enhancing efficient and effective service delivery. For inferential statistics both ANOVA and Chi-square hypothesis testing were used to test the variables. The key findings of the research revealed that FBC manages the different types of knowledge but the policies governing the management of knowledge are not popularized to staff to understand about the relevance of the management of knowledge at FBC library. For the ANOVA hypothesis testing, it revealed that the mean of the variables are not statistically different while the chisquare revealed that there is a statistical variance between the means of the variables. However, provision is made for further research to be done in order to complement this current research.

\subsection{Introduction}

As a learning organisation, libraries provide a strong leadership in knowledge management. Libraries improve their knowledge management in all of the key areas of library services. To manage the exponential growth of different types of knowledge, libraries tend to develop their resources, access and knowledge acquisition strategies from printed to electronic and digital resources. Owing to funding constraints, technology, staff and space, libraries now carefully analysed the needs of their users and seek to develop cooperative acquisition plans to meet the needs of users. On this note, Fourah Bay College library (FBC) manages varied knowledge with regards to tacit, implicit and explicit knowledge. Fourah Bay College library has more of explicit/printed knowledge which consist of text books, periodicals (journals, magazines, newsletter) pamphlets, that are manually preserve for lecturers, students, external researchers, administrators to access these knowledge for their individual purposes. These materials are managed by few trained and qualified librarians, para-librarians and non-librarians. For the purpose of this research librarian means staff with post graduate degree in Library, Archives and Information Studies; while para-librarians are staff with graduate degree including certificate and diploma in Library, Archives and Information Studies; and non-librarian are those staff with neither undergraduate nor graduate and postgraduate degree in Library, Archives and Information Studies. Also, some of these non-professional library staff have certain skills that have not been identified by library authorities, such as tacit knowledge which this article will unravel in the subsequent discussion. These skills are beyond 
the library skills that professional staff received couple of years that could be harnessed to deliver valuable services to clientele/users. There is also implicit knowledge in the library such as computerwhich is used by library staff to generate explicit knowledge.

\subsection{Structure of Fourah Bay College library}

FBC Library is a department under Fourah Bay College, University of Sierra Leone that contributes to research, teaching and education. The Library is a four (4) storey-building and each floor is occupied by different sections within the Library unit. The ground floor is occupied by the Librarian's office (Head of the Library), issue desk, catalogue department, and reference section and reception desk. First floor is shared by two departments, one of which is the American Shelf(AS) and Periodicals' Department(PD). The second floor is occupied by the Sierra Leone Collection (SLC) and General Collection(GC). Text Book Collections(TBC) on various disciplines are available on the third floor. The Binary section and the Cafeteria are available on the lower ground floor. Thus functions of the aforementioned are properly explained in details (Lahai, 2018: 6)

The Librarian's Office controls all other areas in the library. The office also serves as the Acquisition's Department (AD). This is where selection of library materials is done. Lecturers are encouraged to make selection of materials to be acquired for their use.

The cataloguing section is out of bounds to users. The organisation of explicit knowledge (materials) into a set pattern of classes facilitates the arrangement of these materials on the appropriate shelves with materials on specific subjects being housed together in the same area of the library. The excellence of the Catalogue is the pride of the library because once a material is wrongly classified and shelved, it does not stay with members of its class and in some cases, it is like a lost material.

The issue desk section is also called the Circulations Department(CD) where materials that go out on loan are charged to patrons and discharged on return to the library. Information about materials not found where they belong on the shelves could be retrieved from the Circulations Section. Shelving arrangements are also under the supervision of the Circulations Section staff. This section also process and issue students library cards.

The Periodicals Section is also called the Journal/Serials Section. It houses quarterly, bi-quarterly, annually, semi-annually publications. These are publications of several volumes which come about at regular intervals and intended to indefinitely continue. Several authors contribute articles to them. They also have distinct titles. At the end of the year, back issues are sent to the bindery to be bound into volumes and stocked in the section for researchers on varied disciplines. This section can also classify and catalogue periodical materials to ease work done by the Cataloguing Department.(Lahai, 2018: 12)

The American Section is the American Shelve. This is located at the first floor of the library together with Periodicals section. It was established in July 2007, after a "Memorandum of Understanding" signed by the then U.S. Ambassador and the then Deputy Chancellor of Fourah Bay College. The purpose was to 
promote public diplomacy of the Embassy of the United States of America in Sierra Leone, hence its name the "American Shelves." Materials housed in this collection are purely American.(Mangay, 2021, personal interview)

The Sierra Leone Collection section houses material about Sierra Leone. Materials in this collection are difficult to weed since they form part of the national bibliography of Sierra Leone. The unit also contains newspapers which are bought daily. This grey literature is unique as the newspaper collection date-back to the 1930 s to present day.(Lavai, 2021, personal interview)

The Text Book Collection is currently the most heavily used section in Fourah Bay College library. It is a closed access collection. This means that materials are not directly available to readers but issued out upon request. Materials in this section cover varied disciplines based on the curriculum of the college. This collection also houses past examination papers of courses taken on campus. Messengers from the library are sent to examination halls with a formal letter from the Librarian requesting copies of examination papers from invigilators. These are eventually sorted out and sent to the bindery department to be bound into volumes. (Coker, 2021, personal interview)

The binary section is located at the Lower Ground Floor and is responsible for the repair of library materials(books). Paperbacks with less than fifty pages are treated as pamphlets and are processed and stocked in boxes. Materials with fifty pages and above are regarded as books and sent to the bindery for hard covers(Kargbo, 2021, personal interview).

All these sections signify that Fouray Bay College library has knowledge management sections/teams headed by senior members of staff. The purpose of this research is to investigate the nature in which FBC library manages its different types of knowledge.

\subsection{Statement of the Problems}

It is a plain fact that organisation right round the globe manages knowledge with varied kinds and they are not without problems:

The foremost problem is managing knowledge with financial constraints. With specific reference to Fourah Bay College library, the limited availability of funds poses the acquisition of updated/current explicit knowledge to allow users access to them.

The reliance on donation by academic libraries in Africa to acquire the varied implicit type of knowledge such as computer gadget which are sometimes sub-standard to meet the needs of users is nothing to talk home about. When this gadgets get damage, the replacement of it parts is a problem to the parent institutions, without option but to abandon them.

Insufficient trained and qualified staff to management these knowledge to its fullest capacity is posing academic libraries a head ache in this era of computer age. Since it is a new subject/discipline in this part of the world, many people are yet to know the importance of it in career development. 


\subsection{Aims and objectives of the Study}

Aim

The main aim of this study is to critically assess the management of knowledge in the improvement of library services at FBC.

Objectives:

The objectives are to:

- identify the types of knowledge managed at FBC library;

- assess the legal framework governing the management of FBC library;

- identify the facilities and equipment in managing knowledge;

- reveal the staff acquisition techniques in managing knowledge; and

- access the relevance of knowledge in improving library services.

\subsection{Research Questions}

The research asked relevant question such as:

- What are the types of knowledge managed at FBC library?

- Are there any policy framework governing the management of knowledge?

- Which facilities and equipment available for managing knowledge?

- Are there any knowledge acquisition techniques?

- What are the challenges and relevancies in managing knowledge?

\subsection{Literature Review}

This part of the study review academic work on some theories of knowledge management and its relevancy by varied authors.

\subsection{Knowledge}

Knowledge includes everything stored in one head, be it skill/talent individual acquires via formal/informal. Formal skill acquisition is derived from schooling; right from pre-primary, primary to tertiary education. Informal skill is the one receives outside schooling. It could also be the one from Cultural Knowledge (CK), Apprentice Training (AT), parental up-bringing, and social interaction. However, this article emphasizes on the formal knowledge acquisition as the best skill for career development in any institution. Ferrett (2000) noted that formal skill acquisition is not the end but a means that everyone should be privileged to pursue for success in and after college. These skills are key to acquire as it enables one to master the act of managerial and academic work. 


\subsection{Tacit Knowledge}

Tacit knowledge is defined as the skills (Lam, 2000), ideas and experience that are stored in people's head but are not codified and are difficult to express (Kumar, 2010). With tacit knowledge, it is uncommon for people to aware what they possess in their heads and cannot easily pass to others. Virtually, extensive personal contact, frequent interaction and trust can be an effective means of transferring tacit knowledge. Chugh(2018) maintained that tacit knowledge is a skill gain from personal experience that cannot be easily written down, express and present in a tangible form. Examples of these skills are: singing and playing musical instrument; sport; oratory; statistical analysis, and driving. These skills are rare in the library and librarians hardly focus on them, but are very important for entertaining users to encourage them visit the library often. Harold(2016) also defined tacit knowledge as the expertise and experienced harnessed from the librarians for improvement in service delivery in the library. There is also another implicit skill such as on the job training; skill acquired from the job training is the most relevant, backed with education can provide for one livelihood. For the sake of Fourah Bay College library, there are some experienced librarians whose expertise ranges from bibliography, cataloguing, shelving, and collection developments. Thus, these areas of expertise for many staff are difficult to write down or express in the library. Majority can perform the job but cannot express or write it down. For example, if you could tell a non-professional/librarian staff to write how a book binary machine is operated could be a difficult task to write it down.

\subsection{Implicit Knowledge}

Hetherington (2010) revealed that the practical application of explicit knowledge is implicit knowledge. These kinds of knowledge are identifying in Fourah Bay College, University of Sierra Leone. Implicit knowledge/skills are captured and stored in electronic gadget which includes and not limited to computer, mobile, bar code, scanners, facsimile, microfiche, microfilm. The different version of micro-software processing helps in the storage of information which is preserved for managerial and intellectual purposes (Sawyer, 2004: 4). In this knowledge economy, every organisation has varied information stored in the computers. These computers generate and stored information that are tapped from expert's respective tacit knowledge. However, these skills are only limited to few of the staff. This 21 st century knowledge economy mandates every library staff to be computer proficient in delivering library services. The traditional library catalogue system has long been transformed to electronic catalogue system for some libraries in the diaspora. The generation, recipient, storage, and dissemination of information is used for the transaction of businesses and FBC library is not an exception to this new development.

\subsection{Explicit Knowledge}

This type of knowledge is viewed by Cherbet(2013) as a result to captured, processed, organised, structured, stored, and transferred from one person to another. It is easily articulated, communicated and recorded in physical form, which are tapped from individual experiences, skills, history, biography, daily activities of organisations. Explicit knowledge is more dominant in Fourah Bay College library as the custodian of the institution's 'knowledge', in the form of text books, journals, magazines, pamphlets, 
gazettes, newspapers on varied disciplines/subject areas. The rationale for this basically is to provide information for lecturers, students, external researchers, public in order to achieve the ultimate goal of the parent's institution-Fourah Bay College, University of Sierra Leone. He further stated that these skills are as a result of experience of formal knowledge acquisition.

\subsection{Knowledge Management}

Senslly (2002); Cho, Poon and Davis (2008) identified knowledge management as strategic and systematic control of institutional talent/skill regardless of its format, in all categories of media. Bangura (2015) posited that library Knowledge management is the process of collecting, appraising, and controlling tacit, implicit and explicit skills in libraries in order to deliver speedy information transfer to users. Patil (2013) also maintained that knowledge management in libraries should be focused on effective research and development of knowledge, creation of knowledge bases, exchange and sharing of knowledge between library staffs (including its users), training of library staff, speeding up explicit processing and realising of its importance to the library. On this note, Fourah Bay College library has varied information/knowledge assets that it manages in order to educate and make informed decisions. The library collects these materials, classify and catalogue them, using Dewey Decimal Classification Scheme (DDCS). The catalogue card process serves as a direction to give quick access to the library materials on stacks. Thus, the collection and shelving of books on stacks requires special skills. There are librarian, para-librarian and non-librarian staff at FBC library. The managerial skills are attributed to librarians, while the para and non-librarians are attributed to technical skills supervised by the librarians to shelve the process materials; the loan of materials, and the process of library materials for user's utilisation. Poulymennakou, Comford, and Whitley (1990) listed the varied techniques which knowledge should be transferred. They indicated that knowledge is transferred via both formal and informal. Formal knowledge sharing is harnessed from meetings, workshops, seminars, training courses, and tutorials while the informal knowledge sharing is elicited from pear assist, couching, open office, mentoring, after action review and storytelling. Wong and Aspinwalls(2003) revealed that knowledge management policies are the standard guidelines of written information set by senior management in an organisation that is expected by all staff to implement and ensure effective and efficient service delivery which FBC is not an exception. Wamundila(2008), using the 2005 King College formulated strategic policies as thus:

- meet increased users expectations for information access and support

- take advantage of new and emerging technology

- stay competitive within a research and teaching sector

- be more effective as a learning organisation

- work in partnership with the local communities; and

- recognize its responsibilities in a global society.

Ahmed, Lim and Loh(2002) identified facilities, equipment and supplies as a tool for knowledge management practitioners to store and share knowledge and information for the ultimate goal of the academic institution. Kim(2003) on the other hand defined facilities as the factor responsible for 
preserving the different types of knowledge at academic library for information dissemination to users for research/teaching or administrative purposes. While DiMattia and Oder(1997) listed tacit knowledge facilities ranging from conditions of services, workshop, seminars, orientation, meetings, and training courses. These facilities are the bed rock for the motivation of staff in the library and which FBC library is no exception. However, for the facilities and equipment of explicit and implicit knowledge, Ahmed, Lim and Loh(2002) highlighted some of the facilities and supplies which these two types of knowledge should be stored and preserved. They stated metal cabinet, table, comb binder, lettering machine, shelves, files, boxes, pens, binding machine, towel, air conditioner, and kardex as tools for managing knowledge in the library. Thus, without this equipment explicit knowledge will not be properly preserved for users which FBC library cannot be an exception.

Pillai, Gupta, and Saxena(2008) observed that investment in explicit knowledge is a plus, as the parent institution frequently pays the tuition fees for staff who are qualified to pursue undergraduate and postgraduate librarianship course; but the waiver only covers some charges( Grant, 2011). This warrants a challenge to complete the tuition fees payment. Thus, the librarianship course has been given a low moral as compared to other disciplines. Also, there is always a difficulty in entry requirement in the pursuit of librarianship course at diploma and degree level courses. Or some staff are reticent in adding value to the already skilled of the job since their first appointment as library attendance, library assistant, assistant book binder, and book binder. Coker(2021, personal interview) revealed that there is not sufficient sitting accommodation in the library as the population of students keep increasing exponentially. The library is outdated with old text books and periodicals (journals, magazines). There is a bindery section but it has an outdated machines to repair some books (Kargbo, 2021, personal interview).

Jantz(2001) lamented that there is a challenge in acquiring computer gadget and its peripheries; the software packages are hard to get these days. It needs to be frequently changed to meet the demand of technological advancement in this 21 st century. Even, if one had all the technological equipment, without the necessary skills for operation, it means nothing. Virtually, Lahai(2018) confirmed that Fourah Bay College library has some staff that cannot operate the computer desktop very well. This library is deficient with expertise to digitize all the textbooks and journals in order to minimize cost. The bindery section is still in the traditional stage in binding dissertations, theses, pamphlets, textbooks, engagement bible and do not have advanced machines to print books.

King(2009) noted that another challenge faced in most academic libraries for managing knowledge is tacit knowledge. The library authorities do not identify staff with singing ability in music-playing piano, football, cooking, statistical analysis. All these skills are additional value to the library services if well utilised and harnessed. The library is often chosen a noisy place for acting and singing music. As some people learn via by hearing, they acquire their information through music. Thus, extra-curriculum activities are often lacking by staff and users in order to share knowledge.

\subsection{Knowledge management and its relevance to organisations}


Patil(2013) assert that the foremost importance of knowledge in the library is explicit knowledge, because it improves on the delivery of efficient and effective services to the clientele (students, lecturers, external researchers and the public). Over the years the library has trained several staff in both basic and advance librarianship. The library now holds postgraduate and graduate holders in Library, Archives and Information Studies. Training in librarianship is pivotal to all staff in the library; the benefit far exceeded the drawback as great changes are made in the library routine services such as: cataloguing and classification; compilation of bibliography; shelving; and collection development. These skills acquire will bring life changing for now and would be library users. Robertson and Brun(2005) revealed that explicit type of knowledge is the cheapest way of managing knowledge in the library. It is less costly to acquire and less time consuming. Virtually, some academic libraries in Africa are still depended on donation and gift from aluminum members, organisations, or the public which FBC is not an exception. It can allow the users to get quick access to the printed materials, though it is traditional- the materials are not digitised and captured via online. O'Sullivan(2010) indicated that as electronic catalogue system yet to be embraced by staff in academic libraries in Africa, they prefer catalogue card system to electronic catalogue system. On this note, many students and lecturers do not know how to browse the internet to access and retrieve materials online. Thus, the main reason why explicit knowledge management is still acknowledged in Africa, Sierra Leone to be specific, is due to its cheaper rate of collection and can be preserve for a long time than electronic materials which can be easily erased or deleted from the system(King, 2009).

Another very important knowledge the library is worth investing in, is the implicit knowledge. According to the third principle of Ranganatha of library Science, 'A library is a growing organism'(Gossaye, Beshah, and Petit, 2019). It could move beyond traditional library management; this means that library should transform to electronic library services such as E-cataloguing, E-printing using electronic gadget such as computer, bar codes, scanners, and printing machines. The electronic catalogue system is the best way to get quick access to text books, journals, magazines(Dalkir, 2005). Against this backdrop, some sections of the FBC library have completed their electronic catalogue digitisation while few sections are still working on it(Lahai, 2020, personal observation). Sanchez(2001) asserted that explicit knowledge is very important as it enables digitasation of most used library materials compared to countries such as Ghana, Nigeria, South Africa and few American countries. This digitisation will also create internet facility to the library, which users will access at a distance. Nevertheless, Fourah Bay College is yet to attain this new development; although, it has provided internet facility to access online library materials from varied disciplines for lecturers, students, external researchers and the public.

The least importance of knowledge managed in the library is tacit knowledge; tapping the skill of staff in music-playing piano, comedy, oratory, football, cooking, and driving, is very significance as it encourages more users to come to the library. A library should identify staff with talent so that more users visit it. These are extra curriculum activities that library should do infrequently (Lavai, 2021, personal interview).

\subsection{Methodology}


Research methodology is a technique (Oliver,2003), involves in collecting, analysing research data from field of study. This could be quantitative research approach. For qualitative technique, it relates to interviews, observations, and group discussion for collecting data. For quantitative approach, questionnaires are used in collecting data. For the purpose of this research, both techniques are used to collect data because the researcher tends to get into the real problems of knowledge management in FBC library.

\subsection{Variables}

McComes (2021) Identifies research variables as a representation of outcome of the study under phenomenon. This study considers certain variables in the management of knowledge at FBC library. These variables are: types of knowledge management, facilities, equipment, informal knowledge, knowledge acquisition, policies for knowledge management, relevance, formal knowledge management, and challenges.

\subsection{Population}

Population is the set of object from which a subset may be drawn (Merriam, 2009). This means that it is the entire group of people, object or event in a category. In this research, 33 staffs of FBC library are targeted. These staff members are divided into Senior Staff Cadre, Senior Supporting Staff Cadre and Junior staff cadre. Five (5) Senior Staff Cadre, 4 Senior Supporting, and 24 Junior staff.

\subsection{Sample}

Sample relates to a small portion of participant recruited from population to have their opinion or situation under investigation (Dawson, 2009). There are two types of sampling method: They are nonprobability and probability sampling method.

Non-probability sampling method is the method of selecting few participants from the population who are not representative of the sample frame(Mason, 2010), while probability sampling method indicates the selection of samples that represent the entire population. So all samples selected were of an equal chance of selections (Neuman, 2011)). However, the researcher uses both sampling methods to recruit participants for the research project. Also, for non-probability sampling, purposive and convenience sampling are used. The reason for this is that it was simple and convenience for the researcher to get access to the participant at any time.

For probability sampling method, simple random, systematic and stratified sampling methods are used to acquire the sample size. In this study, the researcher put more emphasis on the stratified simple random sample method to get the sample size from the population, which are divided into 3 categories: 13 senior staff, 3 Senior Supporting Staff and 22 Junior Staff. This technique was used because it is straightforward and also simple and can be used in research which the population are diverse in their characteristics (Salkind, 2006).

\subsection{Instrumentations}


The research instrument for this study is qualitative - observation, and interviews, which was used as a tool to assess the management of knowledge at FBC Library, on some participant (Lindlof and Taylor, 2011). Not only were that, information also collected from text books, journals and internet, were used as literature review. For quantitative method, questionnaires were administered to participants involved in collecting data. The reason for using questionnaire is to reach wider participant, increase reliability of result and to minimize biasness in the result that observation and interview method causes in conducting research due to a small sample size. The question asked in this survey addressed a broad range of topics: the personal information of staff(Staff category, department, designation and level of education); the types of knowledge managed; Facilities, equipment and supplies; Legal and regulatory framework; knowledge acquisition techniques; Challenges of managing knowledge; and Relevancy of knowledge management to FBC library. In addendum, a three 3-point and 5-point Likert scales styles were used to frame the close ended questions.

\subsection{Method of data collection}

The researcher has already made a pre interview from some Senior and Junior Staffs relating to research questions that was included in the questionnaire for the actual study. For research to be conducted properly, it is good to pre-test the questionnaire to know if they are properly arranged / straightforward and free from reputation. Thus, the questionnaire was pre-tested to 3 participants. This actually increases the response rate if questions were understood by participants.

This research uses both close and open ended questions to set the questionnaires. Prior to the actual survey, a formal letter was sent to the Senior and Acting Head Librarian FBC library to request permission to administer questionnaires to selected participants, whether through emails or by hand regarding the management of knowledge at FBC library. These questionnaires were administered and completed within two weeks and returned. The collection of data was done by hand. For observation and interview, face to face method was used to collect data based on the critical nature knowledge management is done at FBC library.

\subsection{Method of Data Analysis}

Lahai (2021:8) defined data as a piece of raw information collected from the research field. This study uses mixed method approach in analysing the research data collected from the field, FBC library. One of this mixed method approach is quantitative research method which indicates the use of figures or numbers in analysing the research report. Not only the figure, graph, chart were used to analyse the research data from the questionnaires. For qualitative research method, the researcher uses content analysis and thematic technique in analysing the data from interviews and observations. The reason for using mixed method approach is to achieve a reliable result which is free from biases. Thus the quantitative data were analysed using SPSS version 16(Free encyclopedia, 2021a). The Analysis of Variance (ANOVA) and Chi Square test are used to test the variable at $5 \%$ significant level. The reason for using ANOVA is to compare the means of independents variables that have been listed above. One way ANOVA are the best techniques to compare three or more group variables for hypothesis testing while the 
Chi Square test compare only one or two means (Free encyclopedia, 2021b). The use of ANOVA was not enough to confirm the correctness of the null hypothesis as against the alternative hypothesis.

\subsection{Results And Discussions}

This part provides both qualitative and quantitative data analysis derived from techniques indicated in the methodology. Data obtained from questionnaire are presented in the form of frequencies (number of staff), percentages, and bar charts. Responses were computed using Statistical Packages for Social Sciences (SPSS version 16) followed by discussion from interview, observation, reports, books, journal articles downloaded from internet on the management of knowledge at Fourah Bay College library.

From table 4.0.1 below, the valid percent shows the actual percentage of each frequency while the cumulative percentage is the continuous additions of each valid percent unto one hundred percentages as the threshold point. On the other hand, the cumulative percent column determines us to prove whether or not the computation is complete hundred percent $(100 \%)$. Thus, it is evident that valid percent has a proportional relationship with cumulative percent. However, this research only takes into cognizant a valid percent for further analyses in other to avoid repetition. 
Table 4.0 1. Level of Education (Source: Field data on $3^{\text {rd }}-10^{\text {th }} / 10 / 21$ and SPSS Version 16.0 )

\begin{tabular}{|c|c|c|}
\hline \multicolumn{3}{|c|}{ Statistics } \\
\hline \multicolumn{3}{|c|}{ Level of Education } \\
\hline \multirow[t]{2}{*}{$\mathrm{N}$} & Valid & 33 \\
\hline & Missing & 1 \\
\hline \multicolumn{2}{|c|}{ Std. Error of Mean } & .275 \\
\hline \multicolumn{2}{|c|}{ Range } & 4 \\
\hline
\end{tabular}

\begin{tabular}{|c|c|c|c|c|c|}
\hline & & Frequency & Percent & $\begin{array}{l}\text { Valid } \\
\text { Percent }\end{array}$ & $\begin{array}{l}\text { Cumulative } \\
\text { Percent }\end{array}$ \\
\hline \multirow[t]{6}{*}{ Valid } & MPhil/MA LIS & 5 & 14.7 & 15.2 & 15.2 \\
\hline & BA LIS & 5 & 14.7 & 15.2 & 30.3 \\
\hline & DIP LIS & 4 & 11.8 & 12.1 & 42.4 \\
\hline & CERT LIS & 3 & 8.8 & 9.1 & 51.5 \\
\hline & $\begin{array}{l}\text { Qualification in other } \\
\text { disciplines }\end{array}$ & 16 & 47.1 & 48.5 & 100.0 \\
\hline & Total & 33 & 97.1 & 100.0 & \\
\hline Missing & System & 1 & 2.9 & & \\
\hline Total & & 34 & 100.0 & & \\
\hline
\end{tabular}

The table 4.0.1(up) indicates that the standard error of mean is 0.275 and the range value is 4 ; while table 4.0.1 (down) shows that 15.2 valid percent of five staff have master's degree qualification in Library, Archive and Information Studies (LIS), 15.2\% $(f=5)$ have bachelor of Arts degree in LIS, $12.2 \%(f=4)$ have Diploma in LIS, 9.1\%(f=3) have Certificate in LIS, and 48.5\%( $\mathrm{f}=16)$ have qualification in other disciplines. For the other disciplines, it was revealed that only one staff has master degree in theology, one staff has degree in economics and the rest have certificate in Business Studies, computer and others in West Africa Senior Secondary School Certificate (WASSCE)/Ordinary Level certificate (O'Level).

It is invisible to reveal that, $24.2 \%(f=8)$ participants of staff have spent $0-5$ years on the library job at FBC library, $15.3 \%(f=5)$ staff has spent $6-10$ years, $9,1 \%(f=3)$ staff have spent $10-15$ years, while $51.5 \%(f=17)$ staff spent 15 years and above on the library job. 


\subsection{Types of Knowledge Management}

The part displays the different types of knowledge managed at Fourah College library, and this knowledge could be tacit, implicit and explicit knowledge. Tacit knowledge is knowledge embedded in the staff which could be experiences attained from library work or additional skills derived outside library discipline but can be used to facilitate library services. While the implicit knowledge is the new knowledge that is reside in computers which library staff should embrace. And the explicit knowledge is the one recorded in books, journals, pamphlet, and gazette which are shelved on stacks in libraries.

Figure 1. Types of Knowledge (Left) and Error bar(Right)(Source: Field Data on $3^{\text {rd }}-10^{\text {th }} / 09 / 2021$; SPSS Version 16.0)

From figure 1 (left), $15.2 \%(f=5)$ staff revealed that FBC library has tacit knowledge, $21.2 \%(f=7)$ has implicit knowledge, while $63.6 \%(\mathrm{f}=21)$ of the staff indicated that there are lots of explicit knowledge managed at FBC library. For tacit knowledge, they stated cataloguing and classification skill, shelving books, processing library cards, gold lettering, comb binding and sewing of books, indexing, acquisition. The implicit knowledge indicated by those staff are basic computer skills usage in discharging library services such as electronic cataloguing digitisation and transmission of information via new media.

From chart 1(left), the highest bar represent explicit knowledge. On this note, Cherbet (2013); Choi et al. (2008) coined explicit knowledge as a result of captured, processed, organised, structured, stored, and transferred from one person to another. It is easily articulated, communicated and recorded in physical form, which are tapped from individual experiences, skills, history, biography, daily activities of organisations. Lahai(2021, personal observation) also supported Cherbet opinion about explicit knowledge that they are found all over Fourah Bay College library such as text books, journal, magazines, gazette, newspapers, and bibliographies. This type of knowledge has been the most used collections in the college since its inception and up till now proving to be the most dominant knowledge. The chart also portrays a second highest bar representing implicit knowledge as per the percentages. As indicated by Hetherington (2010) posited that implicit knowledge is the practical application of explicit knowledge. There are possibly these kinds of knowledge all around Fourah Bay College, University of Sierra Leone. This type of knowledge/skill is stored in electronic gadget-such as computer, mobile, bar code scanners, facsimile, microfiche, microfilm. The micro processing software helps in the storage of information which are stored for managerial and intellectual purposes (p.3). Nowadays every organisation has a lot of information stored in the computers. These computers create and stored information that are tapped from experts' respective skills. Bangura(2015) also mentioned that it was from the listed implicit knowledge that text books, journals were created and printed. It is a form of new knowledge for the purpose of this research to replace the old form of knowledge in the FBC library which is still not sufficiently provided to meet the growing demand of users. However, as depicted from the chart, the lowest bar indicating explicit knowledge such as the skills acquired by staff on the job from the length of service in the library is not encouraging. Against this background, Harold(2016) indicated that tacit knowledge is the expertise and experienced harnessed from the librarians for effective service delivery in 
the library. However Chugh(2018) argued that tacit knowledge is the skill one gain from personal experience that is more difficult to write down, articulate and present in a tangible form. He indicated examples as: singing and playing musical instrument; sport; oratory; statistical analysis, and driving. These skills are hard to come by in the library and librarians do not concentrate on them, but they seem vital for improvement of library services.

\subsection{Legal/Policy Framework}

This part explained the policies governing the management of knowledge at FBC library. Policy for this research means the procedures, guidelines and practices governing knowledge management at FBC library.

Figure 2. Legal/Policy Framework (Left) and Error bar (Right)(Source: Field Data on $3^{\text {rd }}-10^{\text {th }} / 09 / 2021$; SPSS Version 16.0)

From figure 2(left), the chart revealed that $57.6 \%(f=19)$ staff indicated whether or not policy exist for the management of knowledge at FBC library. While $24.2 \%(f=8)$ indicated a "yes" that there exist policy governing the FBC library knowledge managemnt and $18.2 \%(f=6)$ selected "no"that FBC library do not have policy to govern the day-to-day management of the different types of knowledge.

From figure 2, it is evident that the highest bar revealed that FBC library staff are not aware of any written policy governing the affairs of the management of knowledge.These participants stated that since they stated working in the library sort policy has not been revealed to them. Against this backdrop, Skyrme (2002) noted that knowledge management policies are the written standard guidelines set by senior management in an organisation that is expected by all staff to implement and ensure effective and efficient service delivery which FBC is not an exception. The chart also revealed the second highest bar participants who indicated that there is policy governing the management of knowledge especially explicit knowledge. In line with this, Wamundila(2008), revealed the King College strategic knowledge management policies as thus:

- information access and support for meeting the needs of users

- to embrace the emerging new technology

- to work competitively within a research and teaching sector

- be more effective and efficient as a learning organisation

- work in collaboration with the other academic libraries, local communities; and

- acknowledges its responsibilities in a global society(Wong and Aspinwall,2004).

The participants who stated the existence of policies at FBC library for the management of knowledge noted that some of these policies have never been popularized to properly explained to staff for better comprehension. This connotes that the policies just exist in vacuum. It was also discerned that the policies are seldom updated in order to retain their relevancy. However, the lowest bar chart could explain 
that policies never existed in the library for the management of knowledge, if there is any but it is not of their knowledge. Contrary to this, Jantz(2001) reiterated that any academic library without knowledge management policies would hardly satisfy the needs of it numerous users.

\subsection{Facilities, Equipment, Supplies of Knowledge Management}

This basically means the things library uses to create, process, store, and preserve knowledge of varied categories. It could also denote the creating of content and the dissemination of information to users of library.

Figure 3. Facilities, Equipment and Supplies (Left) and Error bar(Right)(Source: Field Data on $3^{\text {rd }}$ $10^{\text {th }} / 09 / 2021$; SPSS Version 16.0 )

The chart 3(left) depicts that $18.2 \%(f=6)$ indicated "Cabinet, files, printer and computer" in their unit/collection; $21.2 \%(f=7)$ listed "Table, pen, pencil and papers"; $27.3 \%(f=9)$ indicated "Metal shelf, pamphlet box and kardex" in their collection; $15.2 \%(f=5)$ listed Internet(wifi), web portal, whatSapp, emails and electronic databases are facilities used in their collection; while $18.2 \%(f=6)$ indicated "Condition of services, compensation, collaboration, team work and knowledge sharing" are facilities utilized by staff in managing knowledge at FBC library.

From figure 3(left), it is evident that the highest bar which represent metal shelf, pamphlet box and kardex are the equipment and facilities provided to store explicit knowledge. Other facilities and equipment were noted such as combing machine, lettering machine, sewing machine, and gelatin machine to repair and preserve explicit knowledge. On this note, Ahmed, Lim and Loh(2002) posited that facilities, equipment and supplies are tools used by knowledge management practitioners to store and share knowledge and information to deliver library services. Kim(2000) in support of Ahmed, Lim and Loh)2002) maintained that facilities are the factor responsible for preserving the different types of knowledge at academic library for disseminating information to users for research/teaching or administrative purposes. The second highest bar in the chart revealed table, pen, pencil, and papers as supplies to records and classifies the explicit type of knowledge for easy location on shelves. The third highest bars represent cabinet, files, printer and computer; as well as internet(wifi),web portal, WhatSapp, emails and electronic databases are equipment and facilities used to create knowledge and disseminate them to users especially computer and wifi to satisfy users. Ahmed, Lim and Loh(2002) listed some of the facilities and supplies which these two types of knowledge should be stored and preserved. They stated metal cabinet, table, comb binder, lettering machine, shelves, files, boxes, pens, binding machine, towel, air conditioner, and kardex as tools for managing knowledge in the library. Thus, without these equipment explicit knowledge will not be properly preserved and maintained for users to get quick access to them which FBC library cannot be an exception. The lowest bar in the chart revealed facilities including condition of services, compensation, collaboration, team work and knowledge sharing as very key to motivate staff in delivery effective and efficient service to the clientele. Notwithstanding, DiMattia and Oder(1997) out listed tacit knowledge facilities ranging from conditions of services, workshop, seminars, 
orientation, meetings, and training courses. However, tacit knowledge facilities are the bed rock for the motivation of staff in the library for which FBC library is no an exception. It was also revealed that these facilities are good but not sufficient for the management of knowledge at FBC library.

\subsection{Staff Knowledge Acquisition Techniques}

This reveals the skills/competency of FBC library staff in managing knowledge. Skill is a special talent acquired from informal and formal means to execute professional duties for the sake of this research.

Figure 4: Staff Skill/competency in Managing Knowledge (Left) and Error bar(Right)(Source: Field Data on $3^{\text {rd }}-10^{\text {th }} / 09 / 2021$; SPSS Version 16.0 )

From figure 4(left) extrapolates $90.9 \%(\mathrm{f}=30)$ staff stated "Yes" that they have skills in managing both implicit and explicit knowledge, while $9.1 \%(f=3)$ staff indicated that they do not know whether or not they have skills in managing these knowledge at FBC library and no staff actually indicated that they are not skillfull in delevery the day-to-day affais of the libary.

From chart(4) left, it is quite evidence that FBC library staff are competent in managing the types of knowledge based on the level of education they possess. Justifiably, Harding, Lavai, Sesay, and Rogers(2021, personal interview) observed that investment in explicit knowledge pays a great deal, as the parent institution often pays the tuition fees for staff who are qualify to pursue undergraduate and postgraduate librarianship course( Harding, 2021, personal interview). In fact, each department in the library is headed by postgraduate and undergraduate degree holders in library, Archives and Communication Studies with only one section, that is, the binding section not headed by neither postgraduate nor undergraduate degree holder. It was also revealed that staff acquire knowledge both formal and informal to improve their library skills. For formal skills acquisition, they stated meetings, seminars, internal and external training course, knowledge fairs and tutorials. However, majority indicated meetings and internal training course as knowledge acquisition techniques. Further, the informal skill acquisition techniques stated by the same staff who indicted a "yes" listed open offices, cafeteria, peer assist, after action review, mentoring, and couching for delivery effective and efficient service to users in the library. On the contrary, Davies(2018, personal interview) lamented that the entry requirements into the degree and diploma programme at FBC seem complex for majority of the staff. Or some staff do not like to add value to the skill they have acquired from the job since their appointment as library attendance, library assistant, assistant book binder, and book binder.

\subsection{Challenges of Managing Knowledge at FBC Library}

For the purpose of this research, challenges could mean the foreseen things lacking in the management of knowledge. It could also mean the problems facing staff in managing knowledge.

Figure 5: Challenges staff face in Managing Knowledge (Left) and Error bar(Right)(Source: Field Data on $3^{\text {rd }}-10^{\text {th }} / 09 / 2021 ;$ SPSS Version 16.0 ) 
Figure 5(left) portrays that $87.9 \%(f=29)$ staff indicated "yes" they face challenges in managing the different types of knowledge at FBC library, while $12.1 \%(f=4)$ staff indicated that they do not know whether or not there are challenges facing staff in the management of knowledge, and no staff indicated "no" that there are challenges facing staff in the management of knowledge.

From chart 5(left), the highest bar is representing that there are challenges facing the management of knowledge at FBC library. As indicated by Kargbo(2015, personal interview) lamented that there is a challenge in acquiring computer gadget and its peripheries; the software packages are hard to get these days. It needs to be frequently changed to meet the demand of technological advancement in this $21^{\text {st }}$ century. Even, if one had all the technological equipment, without the necessary skills for operation, it means nothing. Virtually, the Fourah Bay College library has ninety-five (95\%) of staff that cannot operate the computer gadget very well(Harding, 2021, personal interview). This library has no one with the experience to digitize all the textbooks and journals in order to save money. Some of the challenges indicated by these staff are:

- Basic funding to acquire requisite equipment;

- Irregular power(electricity) supply;

- Some explicit knowledge are outdated;

- Wifi connectivity is not strong;

- Entry requirement to offer basic certificate unto degree course in librarianship is high; and

- Insufficient computer gadget.

King(2009) asserted tacit knowledge is another challenge faced in most academic libraries for managing knowledge. It is a fact that most library authorities do not have staff with singing ability in music-playing piano, football, cooking, statistical analysis. These skills add value to the library services when well maintained and utilised. In terms of music a library should be a noisy place sometimes. As some people can learn faster by hearing, they acquire their information through music. Thus, there is a collaboration challenge amongst users and library staff in the aspect of extra-curriculum activities to bind them together in order to share knowledge.

\subsection{Relevance of Knowledge Management to FBC library}

This entails the importance of knowledge to an organisation in order to achieve it ultimate goal. For the sake of library, the old knowledge and the new knowledge in this twenty first century is vital as it improve its services to users.

Figure 6: Relevance of Managing Knowledge to FBC Library (Left) and Error bar(Right)(Source: Field Data on $3^{\text {rd }}-10^{\text {th }} / 09 / 2021$; SPSS Version 16.0 )

Figure 5 (left) revealed that $12.1 \%(f=4)$ staff strongly agreed that the management of knowledge at FBC library is relevant. While $84.8 \%(\mathrm{f}=28)$ agreed that the management of knowledge is vital because it 
imoroves on the quality of research, teaching and learning. And 3.0\% $(f=1)$ staff indicated they do not knowledge whether or not knowledge management is relevance to FBC library. However, no staff indicated strongly disagree and disagree options for the importance of knowledge management at FBC library.

From chart 6 (left), it is evident that the higest bar correspond to eighty-four point eight percent of staff who indicated that the management of knowledge at FBC library is relevance. Consistent with this analogy, Patil(2013) made a logical contribution connoting explicit knowledge as the foremost type of knowledge in the library, because it improves on the delivery of efficient and effective services to the users (students, lecturers, external researchers and the public). In this $21^{\text {st }}$ century the library has trained several staff in both basic and advance librarianship. The library now has both graduate and postgraduate holders in Library, Archives and Information Studies. Training in librarianship is beneficial to all staff in the library; the benefit is far greater than the losses as changes are made in the library services such as: cataloguing and classification; compilation of bibliography; shelving; and collection development. These skills acquired will improve on the library services for now and would be generations. This same staff maintained that the importance of knowledge boosts the efficiency of the Library's decision-making ability. In making sure that all employees have access to the overall expertise held within the organisation, as smarter workforce is built who are more able to make quick, informed decisions that benefit the parent institution.

Also, another very important knowledge management that should be invested in is implicit knowledge. The third principles of Raganatha of library science state, 'A library is a growing organism'(Gossaye, Beshah, and Petit, 2019). It could move beyond the old idea of keeping custody of books and concentrate on content creation; this means that library should transform to electronic library services such as Ecataloguing, E-printing using electronic gadget such as computer, bar codes, scanners, and printing machines. The electronic catalogue system is the best practice to get fast access to text books, journals, magazines(Kulkarni and Freeze, 2005). Against this backdrop, the FBC library is now transforming into electronic catalogue system, yet few staff of about $5 \%$ have this knowledge(Patil, 2013). Sanchez(2000) noted that explicit knowledge is very important as it enhances digitisation of most used library materials compared to countries such as Ghana, Nigeria, South Africa and few Asian countries. This digitisation will also create internet facility to the library, which users could access anywhere at their disposal. Notwithstanding, Fourah Bay College is still at its embryonic stage of this new development; although, it has provided internet(wifi) facility to access online library materials from multiple disciplines for lecturers, students, external researchers and the public. On the contrary, tacit knowledge is taken as the least knowledge managed in libraries; harnessing the skill of staff in music-playing piano, comedy, oratory, football, cooking, and driving, is very beneficial as it encourages more users visit the library. A library should identify staff with these tacit knowledge skills so that more users visit it. These are extra curriculum activities that some libraries do infrequently (Lavai, 2021, personal interview).

\subsection{Variables and Hypothesis Testing}


The selected variables were tested using ANOVA(Analysis of Variance) to show the differences in means values of independent variables using parameters such as sum of squares(SS), Significance(Sig) value, degree of freedom(df), and Mean Square(MS) respectively. While the Chi-squire Test of certain parameters are used such as $\mathrm{v}(\mathrm{df}), X_{c a l}{ }^{2}, X_{t a b}{ }^{2}$ and $a$ ("alpha" at $5 \%$ significance level) in tabular form in rejecting the null hypothesis and accepting the alternative hypothesis as the true hypothesis. The variables used are as follows: Relevance of Knowledge Management(RKM) as dependent variable; Level of Education(LOE); Types of Knowledge Management(TKM); Legal/Policy Framework)(L/PF); Knowledge Management Acquisition Techniques(KMAT); Facilities, Equipment and Supplies of Knowledge Management(FESKM); and Challenges of Managing Knowledge(CMK).

Hypothesis: Knowledge Management improves on the delivery of services and information dissemination in FBC library.

Null hypothesis $\mathrm{H}_{0}: \mu_{1}=\mu_{2}=\mu_{3} \ldots \mathrm{OR} X_{c a l}^{2}<X_{\text {tab }}^{2}$ OR $\mathrm{F}_{\text {cal }}<\mathrm{F}_{\text {tab }}$ (no significance difference between knowledge management and improvement of library service and information dissemination).

Alternative hypothesis $\mathrm{H}_{\mathrm{A}}: \mu_{1} \neq \mu_{2 \ldots . . .}$ OR $X_{c a l}{ }^{2}>X_{t a b}{ }^{2}$ OR $\mathrm{F}_{\text {cal }}>\mathrm{F}_{\text {tab }}$ ( at least two of the mean show significance difference between knowledge management and improvement of library services and information dissemination)

Note that when $\mu_{1} \neq \mu_{2} \neq \mu_{3}$ OR $X_{c a l}^{2}>X_{t a b}^{2}$ (>greater than) reject $\mathrm{H}_{\mathrm{O}}$ and accept $\mathrm{H}_{\mathrm{A}}$ and $(\mu)$ is the population mean. For ANOVA table below, the significance figure in the last column is taken in to cognizance as any value below $a$ ("alpha" at $5 \%$ significance level) then the null hypothesis is rejected otherwise we accept the alternative hypothesis. This means that knowledge management enhances the improvement of library services and information disseminations at FBC library. Also, note that in the ANOVA table $F_{\text {cal }}$ means $F$ statistics, $F_{\text {tab }}$ denote $F$-critical level derived from the statistical table and $D f=$ $k-1, n-k$ respectively.

Also, for Chi-square test, the decision rule is to reject $\mathrm{H}_{0}$ if the computed value of $X_{c a l}{ }^{2}<X_{t a b}{ }^{2}$ while we accept $\mathrm{H}_{\mathrm{A}}$ when $X_{c a l}{ }^{2}>X_{t a b}{ }^{2}$. Assuming that $\mathrm{H}_{0}: \delta_{1}=\delta_{2}=\delta_{3}$ and $\delta_{1} \neq \delta_{2} \neq \delta_{3} \ldots$. Where $\delta$ is population variance and (df) is the degree of freedom. Note that the test is a two tailed test at $5 \%$ significance difference of $95 \%$ confidence interval.

\section{Table4.0.2: ANOVA Testing}




\begin{tabular}{|c|c|c|c|c|c|c|c|}
\hline & & $\begin{array}{l}\text { Sum of } \\
\text { Squares }\end{array}$ & $\mathrm{df}$ & $\begin{array}{l}\text { Mean } \\
\text { Square }\end{array}$ & $\mathrm{F}_{\mathrm{cal}}$ & Sig. & $\mathrm{F}_{\mathrm{tab}}$ \\
\hline \multirow[t]{3}{*}{ Level of Education } & $\begin{array}{l}\text { Between } \\
\text { Groups }\end{array}$ & 9.165 & 2 & 4.582 & 1.944 & .161 & $\begin{array}{l}3.32 \\
3\end{array}$ \\
\hline & $\begin{array}{l}\text { Within } \\
\text { Groups }\end{array}$ & 70.714 & 30 & 2.357 & & & \\
\hline & Total & 79.879 & 32 & & & & \\
\hline \multirow[t]{3}{*}{ Types of Knowledge } & $\begin{array}{l}\text { Between } \\
\text { Groups }\end{array}$ & 2.635 & 2 & 1.318 & 2.533 & .096 & 3.32 \\
\hline & $\begin{array}{l}\text { Within } \\
\text { Groups }\end{array}$ & 15.607 & 30 & .520 & & & \\
\hline & Total & 18.242 & 32 & & & & \\
\hline \multirow[t]{3}{*}{ Legal/Policy Framework } & $\begin{array}{l}\text { Between } \\
\text { Groups }\end{array}$ & 3.619 & 2 & 1.810 & 2.754 & .080 & 3.32 \\
\hline & $\begin{array}{l}\text { Within } \\
\text { Groups }\end{array}$ & 19.714 & 30 & .657 & & & \\
\hline & Total & 23.333 & 32 & & & & \\
\hline \multirow[t]{3}{*}{$\begin{array}{l}\text { Knowledge management facilities, } \\
\text { Equipment, and Supplies }\end{array}$} & $\begin{array}{l}\text { Between } \\
\text { Groups }\end{array}$ & 1.299 & 2 & .649 & .351 & .707 & 3.32 \\
\hline & $\begin{array}{l}\text { Within } \\
\text { Groups }\end{array}$ & 55.429 & 30 & 1.848 & & & \\
\hline & Total & 56.727 & 32 & & & & \\
\hline \multirow{3}{*}{$\begin{array}{l}\text { Staff skill/competency in } \\
\text { managing knowledge at FBC } \\
\text { library }\end{array}$} & $\begin{array}{l}\text { Between } \\
\text { Groups }\end{array}$ & .195 & 2 & .097 & .273 & .763 & 3.32 \\
\hline & $\begin{array}{l}\text { Within } \\
\text { Groups }\end{array}$ & 10.714 & 30 & .357 & & & \\
\hline & Total & 10.909 & 32 & & & & \\
\hline \multirow[t]{3}{*}{$\begin{array}{l}\text { Staff Acquisition of Knowledge } \\
\text { Management Techniques }\end{array}$} & $\begin{array}{l}\text { Between } \\
\text { Groups }\end{array}$ & .113 & 2 & .056 & .191 & .827 & 3.32 \\
\hline & $\begin{array}{l}\text { Within } \\
\text { Groups }\end{array}$ & 8.857 & 30 & .295 & & & \\
\hline & Total & 8.970 & 32 & & & & \\
\hline $\begin{array}{l}\text { Challenges in Managing } \\
\text { Knowledge Management }\end{array}$ & $\begin{array}{l}\text { Between } \\
\text { Groups }\end{array}$ & .346 & 2 & .173 & .379 & .688 & 3.32 \\
\hline
\end{tabular}




\begin{tabular}{|c|c|c|c|c|c|}
\hline & & \\
\hline & & $\begin{array}{l}\text { Within } \\
\text { Groups }\end{array}$ & 13.714 & 30 & .457 \\
\hline Total & 14.061 & 32 & & & \\
\hline
\end{tabular}

(Source: Field Data; SPSS Version 16.0 and Probability distribution table)

The table 4.0.2 of the ANOVA result revealed that all the values in the significance column are above the 0.05 alpha(a) calculated level of significance(sig). The decision rule for supporting the null hypothesis is eminent for $F_{t a b}=3.32$ being higher than all the values in the $F_{c a l}$ column of ANOVA table. This means that the mean values of the variables (within and between groups) are equal. And we accept the null hypothesis and reject the alternative hypothesis that says "the mean values of variables are not equal." However, the power of parametric testing is beneficial as it prevents against the commission of type 1 error in hypothesis testing since the null hypothesis was not rejected by chance.

\section{Table 4.0.3: Chi-square Test of independence}

\begin{tabular}{|lllllll|}
\hline Variables & $\mathrm{df}(\mathrm{v})$ & $X_{c a l}{ }^{2}$ & $X_{\text {tab }}{ }^{2}$ & $\boldsymbol{a}$ (alpha) & Range & Standard Error of mean \\
\hline LOE & $\mathbf{4}$ & $\mathbf{1 7 . 1 5 2}$ & $\mathbf{9 . 4 8 8}$ & 0.05 & 4 & 0.275 \\
\hline TKM & $\mathbf{2}$ & $\mathbf{1 3 . 8 1 8}$ & $\mathbf{5 . 9 9 1}$ & 0.05 & 2 & 0.131 \\
\hline L/PF & $\mathbf{2}$ & $\mathbf{8 . 9 0 9}$ & $\mathbf{5 . 9 9 1}$ & 0.05 & 3 & 0.136 \\
\hline KMFES & $\mathbf{4}$ & $\mathbf{1 . 3 9 4}$ & $\mathbf{9 . 4 8 8}$ & 0.05 & 4 & 0.217 \\
\hline SAKMT & $\mathbf{2}$ & $\mathbf{1 8 . 1 8 2}$ & $\mathbf{5 . 9 9 1}$ & 0.05 & 2 & 0.092 \\
\hline CMK & $\mathbf{1}$ & $\mathbf{1 8 . 9 3 9}$ & $\mathbf{3 . 8 4 1}$ & 0.05 & 2 & 0.115 \\
\hline SCKM & $\mathbf{1}$ & $\mathbf{2 2 . 0 9 1}$ & $\mathbf{3 . 8 4 1}$ & 0.05 & 2 & 0.102 \\
\hline RKM & $\mathbf{2}$ & $\mathbf{3 9 . 8 1 8}$ & $\mathbf{5 . 9 9 1}$ & 0.05 & 2 & 0.067 \\
\hline
\end{tabular}

(Source: Field data; SPSS 16.0 and Probability distribution table).

For Chi-square test, $87.5 \%$ of the variables did not meet the assumption of equal means when $X_{c a l}{ }^{2}>$ $X_{t a b}{ }^{2}$ and we accept the alternative hypothesis that means are not equal in all respect. Thus, the only variable in the $\mathrm{X}_{\mathrm{cal}}{ }^{2}$ which is lower than the $\mathrm{X}_{\mathrm{tab}}{ }^{2}$ is the Legal/policy framework (L/PF). This signifies that the result is good for non-parametric test because it meets the research hypothesis which states that there is significant difference between knowledge management and improvement in library services and information dissemination at FBC library. Also, the sixth and the seventh column of Table 4.0.3 represent the ranges and standard error of mean which LOE and KMFES has the highest value of $(4,0.275)$ and $(4$, $0.217)$ respectively. 


\subsection{Conclusion}

This work has presented result on knowledge management and improvement of library services and information dissemination at FBC library. Therefore, the following conclusions could be drawn.

The research revealed that FBC library has pool of staff with competency in managing the different type of knowledge, especially the explicit knowledge. There is a policy governing the management of knowledge but are not popularized/well known to staff. There is evidence of knowledge management acquisition technique but these techniques are acquired from more of informal than formal means to deliver effective service delivery. Though there were some challenges in managing knowledge, such as financial constraints, outdated explicit knowledge; however, the relevance of managing knowledge cannot be overemphasised to effectively deliver and disseminate information to users.

The research result, using SPSS revealed that $87.5 \%$ of the variables from the chi-square testing agreed with the research hypothesis that there is significant different between knowledge management and improvement of services and disseminations of information while the ANOVA result contended against the research hypothesis that the mean of variables are not the same. The research uses a $95 \%$ confident interval with a two tailed test of $5 \%$ significance level. Also, the vertical axis of the error bars indicated a positive value of $95 \%$ confident intervals.

\subsection{Recommendations}

After critical statistical analysis of knowledge management at FBC library, it was discovered that the following recommendations should be taken into consideration for further research and implementations of the suggested point highlighted.

The foremost, very significance knowledge/skill that the Fourah Bay College Library does not invest in is the tacit skill. There are staff who can sing and play the piano, football, and cook very well. These set of knowledge should be identified in the library so that they can use their skills to entertain users. For football, the library authority should organise a football competition with the users, wherein those identified footballers will play with the users. Also, music is one medium that library used to encourage users to come to the library. Through music, relevant information can be disseminated about the library. For food, since there is now a Cafeteria at FBC library, staff should be motivated to display the current library holdings at varied sections to users when they come to eat in the FBC Cafeteria. These can also encourage the users to frequently visit the library as the library new services and materials will be displayed. Staff with subject librarian skill such as complex statistical equation analysis skills should be motivated so that, the library will tap into their knowledge to analysing qualitative and quantitative data. It is also, worthwhile to invest in tacit knowledge as there are staff in the library that are closer to retirement age. These staff have reserviour of practical librarianship skills; specially the cataloguing and classification, shelving and collaborative skills. 
Furthermore, another very important knowledge crucial investing in is the implicit type of knowledge. This is exactly the computer which can solve the problem of manual cataloguing and classification, content creation, and networking, data mining and analysis and storage and sharing of internet and external information resources for effective knowledge exchange among users, resources persons(faculty, researchers, subject expert) when it is connected to the internet. It is good that library authorities identify those with computer proficiency skill to browse and retrieve books/journals via online. Thus, I recommend that team/collaborative work is the most important strategy that the library should encourage in order to identify implicit knowledge.

Furthermore, as the name, library denotes the repository of all sort of knowledge/information; it particularly manages textbooks, journals, magazines, pamphlets, memoirs, gazettes, and bibliographies. However, most of these materials are out-dated or damaged. It should be replaced with new ones. It is also recommended that the library encourage more staff to pursue librarianship course; pursuing this course will expand their knowledge for efficient services delivery in the library. It is also recommended to staff with Master of Art(MA) and Bachelor of Art(BA) in the library to emulate the attitude of writing and publishing articles in Library, Archives and Information Services. This can not only take one to higher senior positions in the library, but could add to the respect of library profession. Librarianship is a blessing in disguise; one could learn and master any skill one desires. One could work in the library and attain subject librarianship such as Accounting, Business Management, law, Economics, and ICTs skills.

\section{Declarations}

\section{Conflict of Interest}

The authors declare no conflicts of interest regarding the publication of this paper.

\section{Ethical considerations}

This research seek approval by the Fourah Bay College, University of Sierra Leone Research Committee and granted the researcher to proceed.

Participants were duly informed through a letter of participation in which the researcher requests their consent to participate in the research, taking into consideration the fact that participants are free to answer or not to answer any question they deem it fit to.

\section{Acknowledgements}

This work was not funded by anyone but the author himself.

\section{References}

Ahmed , P K., Lim , K . K. , \& Loh , A.Y. E(2002). Learning through knowledge management. Oxford: Butterworthy-Heineman. 
Bangura, M. F.(2015). Knowledge management. MPhil lesson note for Library. Archive and Information Studies.

Cherbet, Viviane(2013). Type of Knowledge management, knowledge sharing productivity. Available at: https://www.flockr.com/photo/lollyman.( access on $20^{\text {th }}$ June 2020).

Choi, B., Poon, S.K., Davis, J.G.(2008). "Effects of knowledge management strategy on organisation performance: A complementarity theory-based approach," Omega, 36(2), 220-233. Available at: https://www.google.com(accessed on $11^{\text {th }}$ November 2021)

Dalkir, N(2005). "Networks, digital libraries and knowledge management: trends Development," DESIDOC Journal of library \& library \& information Technology, 23(5), 3-11.

DiMattia, S and Order, N(1997). "Knowledge management: Hope, hype or Harbinger? Library Journal," 122(15), 33-35.

Dawson, Dr. Catherine(2009). Introduction to research methods: A practical guide for anyone undertaking a research project. $4^{\text {th }}$ ed. Oxford: Spring Hill House. Available at: www.pdf.com. ( accessed on $10^{\text {th }}$ June 2021).

Ferrett, Sharon K.(2000). Peak performance: success in college and beyond.-3rd ed. New York: McGrawHill.

Free encyclopedia(2021a). What is Analysis of Variance. Available at: http://www.google.com(accessed on $7^{\text {th }}$ September 2021).

Free encyclopedia(2021b). Statistical Packages for Social Sciences(SPSS). Available at: www.google.com(accessed on $7^{\text {th }}$ September 2021).

Gossaye, M; Beshah, T and Petit, J(2019). Knowledge management capability maturity level in selected public university libraries in Ethiopia" Global Scientific Journal, 7(1), 1028-1061.

Grant, K.(2011). "Knowledge management, an enduring but confusing fashion," Electronic Journal of Knowledge Management, 9(2), 95-123

Hetherington, S.(2010). How to know: a practicalist conception of knowledge. London: Wiley-Blackwell. Jantz, R(2001)."Knowledge management in academic libraries: special tools and process to support information professionals," Reference Services Review, 29(1), 33-39.

Kim , Seonghee, 2000. "The role of knowledge professionals for knowledge," Management INSPEL, 34(1), 1-8. Available at: http://www.ifla.org.(accessed on $24^{\text {th }}$ October 2021) 
King, R(2009)." Competing with knowledge: the information in the knowledge management age," Education Libraries Journal, 54(1), 27.

Kumar, S.A.(2010). "Knowledge management and new generation of libraries information services: A concepts," information Journal and Information Science, 1(2), 024-030.

Lahai, Prince Sao Jr.(2018). "The status of Fourah Bay College library since its inception to present moment," Available at: http:// ezinearticle.com/?The-Status-of-Fourah-Bay-College-library-since-itsinception-to-present-moment\&id=9996992. (accessed on October 11, 2021)

Lahai, Prince Sao Jr.(2021). "Sample PhD thesis proposal on the management of public sector records in enhancing good governance in Sierra Leone," Journal Scientific Journal, 9(9), 1529-

1542./VII/d2inspel/index.html( accessed on $9^{\text {th }}$ November 2021)

Lam, $A(2000)$. "Tacit knowledge, organisational learning and societal institution: an integrated framework," Organisation Studies, 21(3), 487-513.

McCombes, Shona(2021). 'An introduction to sampling methods," Available at: Wikipedia, the free encyclopedia(accessed on $24^{\text {th }} / 06 / 2021$ ).

Merriam, S.B.(2009). Qualitative research: a guide to design and implementation. San Francisco: JoeseyBass. Available at: www.books.google.com.sl/books/about/Qualitative_Research.html.pid=tvFLcrgcuSIC \&redir_esc=y (accessed on 13/01/2018).

Neuman, L.W.(2011). Social research method: qualitative and quantitative approach $6^{\text {th }}$ ed. Boston: Pearson. Available at: www.pearson.com/us/higher- education/program/Nueman-social-ResearchMetheis-Qualitative-and-Quantitative- Approach-7 ${ }^{\text {th }}$-edition//RGM74573.html( accessed on 16th/06/2021).

Oliver, P (2003). The student's guide to research. London: Routledge.

Patil, Sudhir S(2013). "Knowledge management in libraries," International Journal of Digital Libraries and knowledge management, 3(2), 71-74.

Pillai, S.; Gupta, R.K, \& SAXENA, K.B.C.(2008). “From rhetoric to reality: an enquiry into Knowledge management initiatives in an organization of higher learning," Journal of Information \& Knowledge Management, 8(2), 79-99.

Poulymenakou, A; Cornford, T and Whitley, A.E(1990). Knowledge acquisition for organizational problem solving: developing expert system and beyond. London: LSE Research Online. Available at: https://www.eprint.Ise.ac.uk/archive/00000275. (accessed on $24^{t}$ October,/2021). 
Robertson, Shaunagh and Brun , Caroline De 2005 ): Developing the knowledge management environment. Knowledge management specialist library. Available at: www. Online.com(accessed on $26^{\text {th }}$ October 2021).

Salkind, Neil J (2006). Exploring research. $4^{\text {th }}$ ed. New Jersey: Prentice Hull.

Sanchez, R.(2000). "Tacit Knowledge" versus "Explicit knowledge”: Approaches to knowledge management practice. Available at : www.ep.lib.cbs.dk/download/ISBN/x65640929x.pdf.(accessed on $4^{\text {th }}$ November 2021)

Sawyer, A..(2004). Challenges facing African universities. Available at: www.africanstudies.org/ChallengesFacing AfricanUniversities.pdf(accessed on 2nd November 2021) Senslly, Tom(2002). “Knowledge Management," Advances in Psychiatric Treatment, 8(5), 87-398.

Skyrme, J.D(2002). “Knowledge management: approaches and policies. David Skyrme Associates Limited." Available at: https://www.providersedge.com/docs/km.articles/km- Approaches and policies.pdf( accessed on $03^{\text {rd }}$ November 2021)

Wamundila, , Sitali (2008).. Developing guidelines for a knowledge management policy to enhance knowledge retention at the University of Zambia. Master Dissertation, University of Zambia, Zambia.

Wong, K.Y \& Aspinwall, E(2004). Knowledge management implementation framework: a review. Knowledge and Process management, 11(2), 93-104.

\section{Figures}

\section{Figure 1}


Types of Knowledge (Left) and Error bar(Right)(Source: Field Data on 3rd-10th/09/2021; SPSS Version 16.0)

Legal/Policy Framework

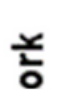

\section{Figure 2}

Legal/Policy Framework (Left) and Error bar (Right)(Source: Field Data on 3rd-10th/09/2021; SPSS Version 16.0)
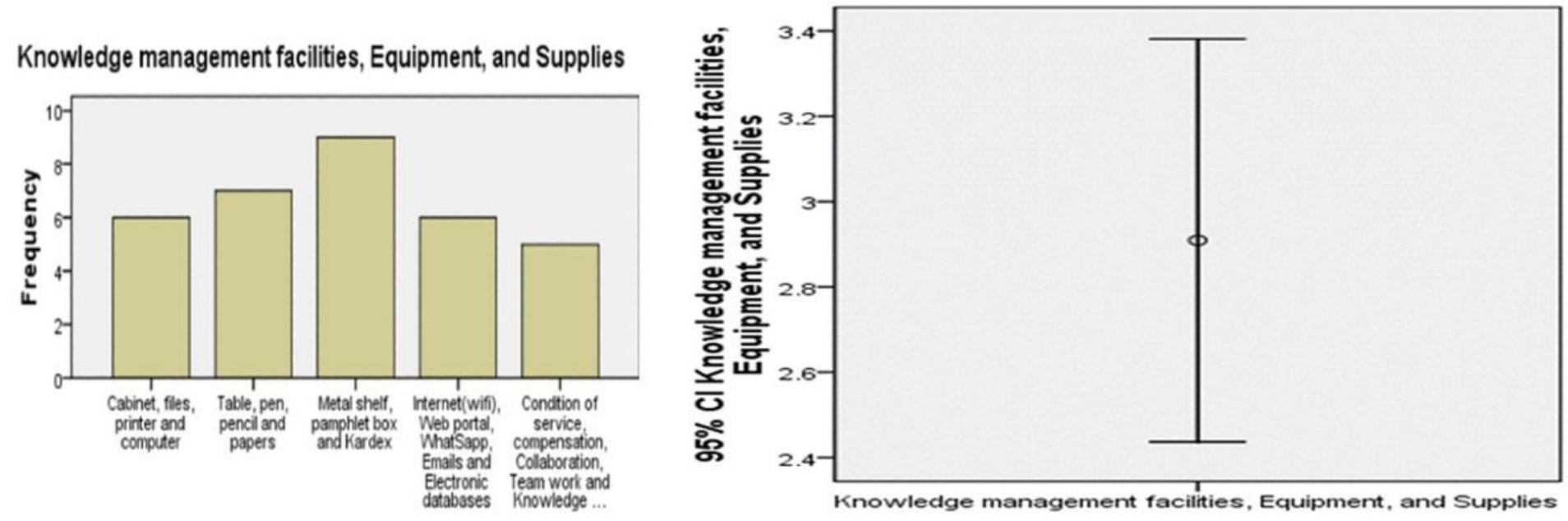

\section{Figure 3}

Facilities, Equipment and Supplies (Left) and Error bar(Right)(Source: Field Data on 3rd-10th/09/2021; SPSS Version 16.0) 

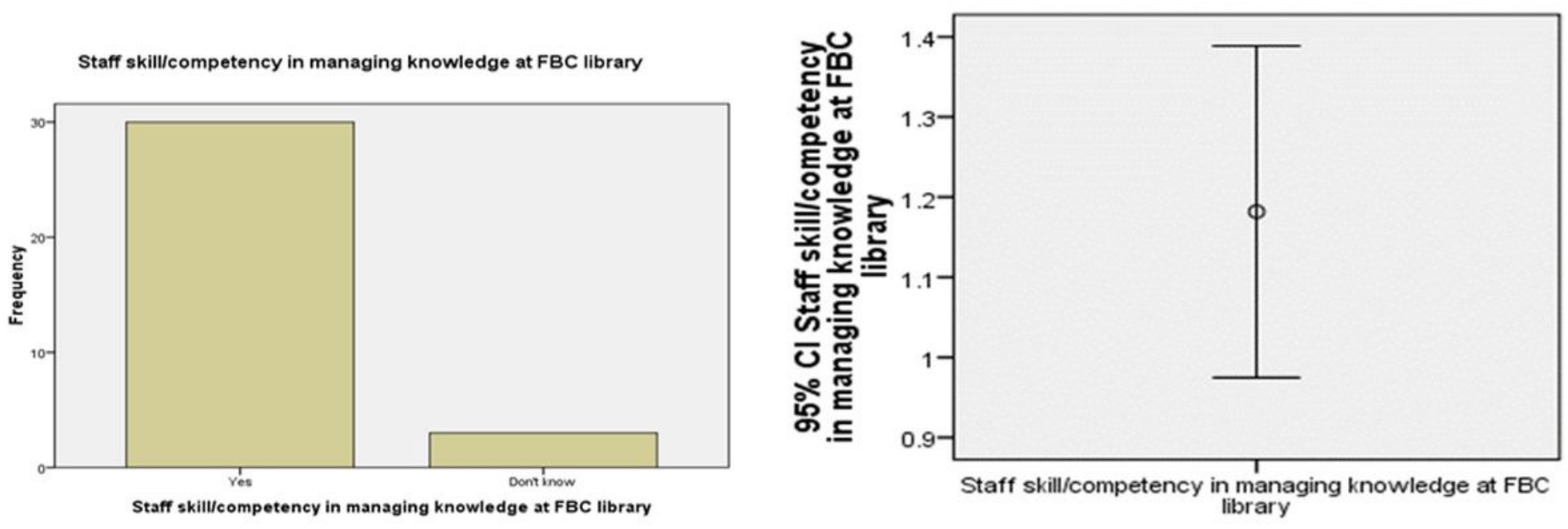

\section{Figure 4}

Staff Skill/competency in Managing Knowledge (Left) and Error bar(Right)(Source: Field Data on 3rd10th/09/2021; SPSS Version 16.0)
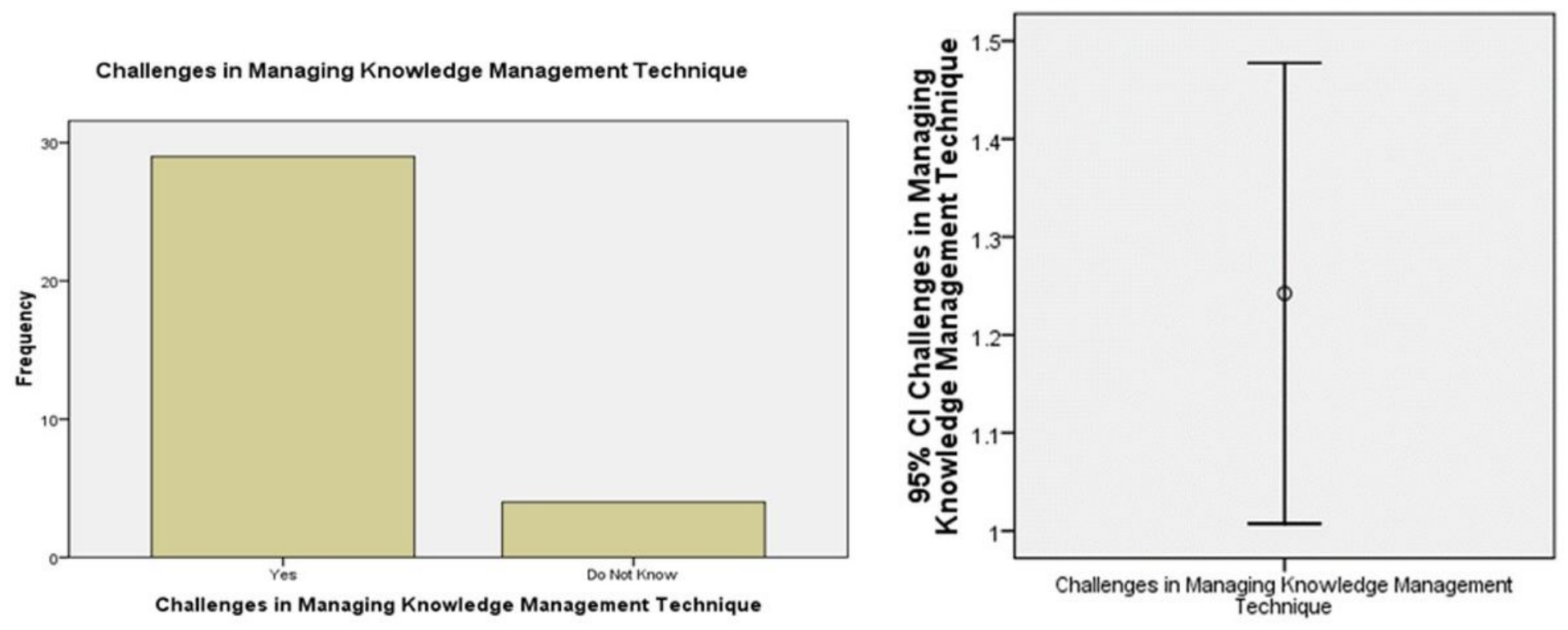

\section{Figure 5}

Challenges staff face in Managing Knowledge (Left) and Error bar(Right)(Source: Field Data on 3rd10th/09/2021; SPSS Version 16.0) 

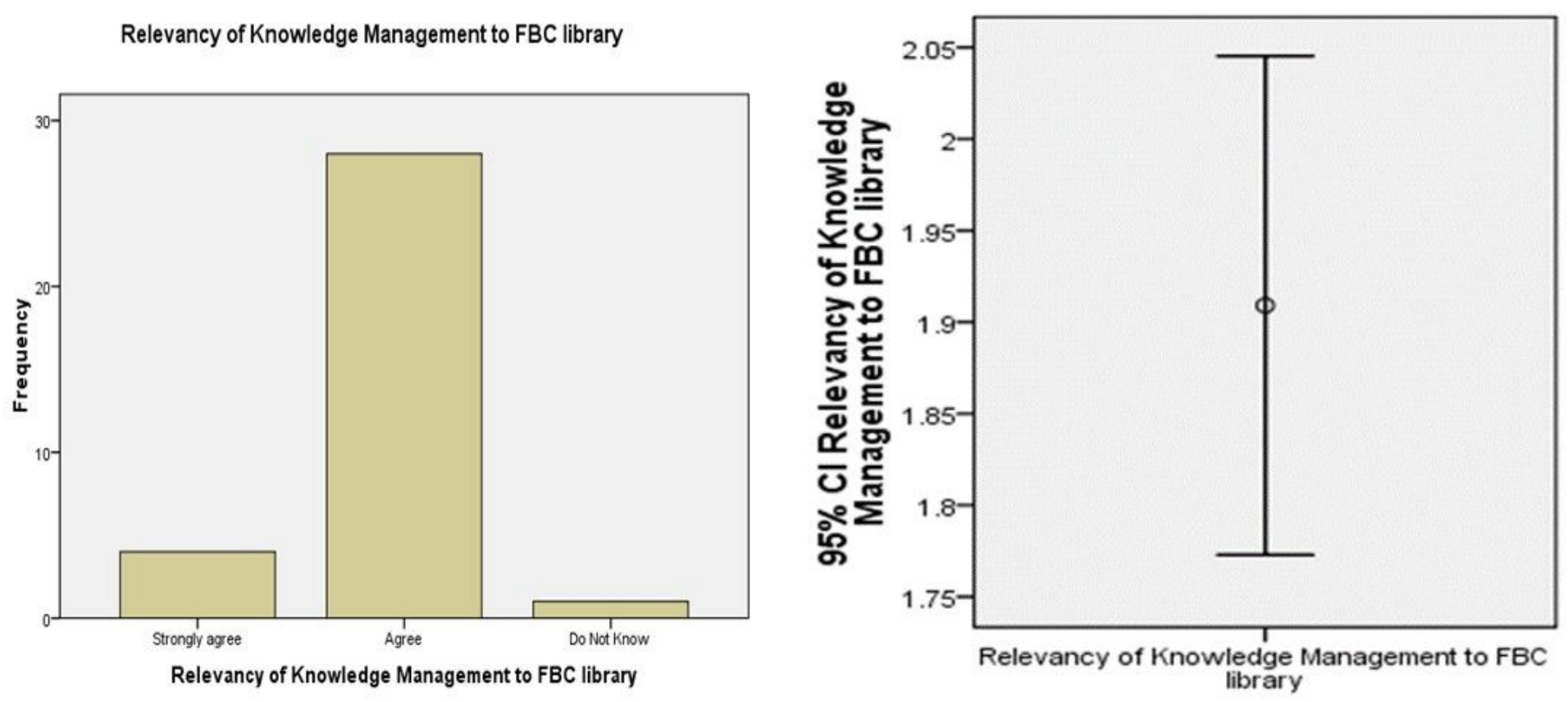

Figure 6

Relevance of Managing Knowledge to FBC Library (Left) and Error bar(Right)(Source: Field Data on 3rd10th/09/2021; SPSS Version 16.0) 